\title{
A recent look for the implication and attitude of practicing female genital mutilation in upper Egypt: a cross sectional study
}

\author{
Abo Bakr A. Mitwaly ${ }^{1}$, Diaa Eldeen Mohamed Abd El Aal ${ }^{1}$, Peter A. Aziz ${ }^{2}$, \\ Ahmed I. Hassanin ${ }^{1}$, Ahmed M. Abbas ${ }^{1 *}$
}

\begin{abstract}
${ }^{1}$ Department of Obstetrics and Gynecology, Faculty of Medicine, Assiut, Egypt
${ }^{2}$ Department of Obstetrics and Gynecology, Luxor General Hospital, Luxor, Egypt
\end{abstract}

Received: 21 July 2017

Accepted: 22 August 2017

\section{*Correspondence:}

Dr. Ahmed M. Abbas,

E-mail: bmr90@hotmail.com

Copyright: () the author(s), publisher and licensee Medip Academy. This is an open-access article distributed under the terms of the Creative Commons Attribution Non-Commercial License, which permits unrestricted non-commercial use, distribution, and reproduction in any medium, provided the original work is properly cited.

\begin{abstract}
Background: Female genital mutilation (FGM) was defined as the partial or total removal of the female external genitalia for non-medical reasons The Demographic and Health Survey in Egypt in 2000 showed that $97 \%$ of married women included in the survey had experienced female genital mutilation.

Methods: This is a cross sectional study to evaluate the current prevalence of FGM, current attitude of our society towards it after illegalization of it as a cross sectional survey of Upper Egypt. The most important point in this study is our evaluation of intention of these women whom exposed to FGM toward mutilation of their daughters or not and reasons for that. Statistical analysis was done using SPSS software version 21.

Results: The study included 1175 women, from whom $89.1 \%$ were circumcised. Type 1 FGM was the most prevalent type practiced in about $58 \%$ of participants. Immediate complications occurred in $42.5 \%$ of women. Primary hemorrhage during circumcision was the most commonly reported immediate complication among $38.5 \%$ of them. Sexual problems were found in $40.5 \%$ of participants. Sixty-four women reported occurrence of hepatitis virus infection after the procedure. Moreover, 44 women were suffered from infertility and 72 women had an episode or chronic PID. Women who intend to circumcise their daughters are mostly those coming from rural areas $(\mathrm{p}=0.000)$ and housewives $(\mathrm{p}=0.000)$. Most of women $(45.8 \%)$ who have the intent to circumcise their daughters claiming that it is religious based.

Conclusions: The prevalence of FGM did not differ between urban and rural or between house wives and employee, lastly did not differ between different educational levels as most of them were encourage it thinking that it is of traditional, religious base and protect the girl from any abnormal sexual excitation. The women who intent not circumcise their daughters were from low educational level in its highest percentage and this was explained by occurrence of higher percentage of complications in spite of the highest percentage of operator was physician.
\end{abstract}

Keywords: Female genital mutilation, Female circumcision, Upper Egypt

\section{INTRODUCTION}

Female genital mutilation (FGM) was defined as the partial or total removal of the female external genitalia for non-medical reasons. ${ }^{1}$ It is not known when and where it was first practiced, but it is thought to have originated in ancient Egypt. ${ }^{2}$ This practice was done by people of all religions, including Christians, Muslims and Jews. ${ }^{3}$ The prevalence counted across 28 African countries from Gambia to Somalia and involving some parts of the Middle East and Asia. ${ }^{1}$ 
The Demographic and Health Survey in Egypt in 2000 showed that $97 \%$ of married women included in the survey had experienced FGM. Another study by the Egyptian Ministry of Health and Population in 2003 reported that over $94 \%$ of married women had been exposed to genital cutting. ${ }^{4}$

The age at which female genital mutilation is carried outranges from early neonatal period up to 10 years. The following are reasons for it: controlling female sexuality; cleanliness; maintaining female virginity until marriage; improving fertility; traditional and cultural practice; and, the belief that it is a religious target. ${ }^{5-7}$

\section{Types of circumcision: as defined by WHO}

- Type (1): Excision of the prepuce with or without excision of part or the entire clitoris.

- Type (2): Excision of the clitoris with partial or total excision of part or all of the labia minora.

- Type (3): Excision of part or all of the external genitalia and stitching/narrowing of the vaginal opening (infibulation).

- Type (4): Unclassified - includes applying corrosive substances for narrowing the vagina, cauterizing, pricking, Piercing, incising, stretching, scraping or other harmful Procedures performed on the clitoris and/or labia. ${ }^{1}$

\section{In most of the studies the following are the complications of FGM}

\section{Immediate complications}

Primary hemorrhage-Infection at circumcision site-Urine retention-dysuria-Injury of vagina,

\section{Sexual problems like}

Disturbance in relationship (loss of libido, sexual desire and failure to reach orgasm)-Non-satisfaction in intercourse-separation from husband,

\section{Physical problems like}

(Chronic pelvic pain-urinary troubles-infertility-serious virus infection like hepatitis),

\section{Obstetric problems}

(Cesarean section due to obstructed labor-Multiple vaginal tears-postpartum hemorrhage). ${ }^{8}$

Some studies found that $46.8 \%$ of circumcised females were unsure whether it would have been better if they had not been circumcised. ${ }^{9}$ This corresponds to that detected in a study by another study in Egypt, which reported that only $12.4 \%$ of the study population intended to discontinue the practice. ${ }^{10}$

\section{METHODS}

A cross sectional survey study to evaluate the current prevalence of FGM, current attitude of our society towards it after illegalization of it as cross-sectional survey of Upper Egypt. The most important point in this study is our evaluation of intend of these women whom exposed to female genital mutilation toward mutilation of their daughters or not and reasons for that, in addition to effect of various factor evaluated in this study upon intent to circumcise their daughters or not.

This study was done through a direct interview in addition to examination of 1175 women of various ages in the reproductive age category, whether circumcised or not, at different social and economic states, during their coming to the reproductive health clinic in general Luxor hospital in Luxor city which is one of the famous governorates in south valley (Upper Egypt), these women were referred from primary care units for reproductive health care. Luxor city has a unique character, being near Aswan, Elnoba and Sudan, with their special culture and believes about female circumcision.

Duration of the study was about 13 months from April 2014 to May 2015. The interview was done by the researchers with help of a female doctor in some cases, in outpatient clinic of Luxor general hospital. The Assiut Medical Ethical Review Board approved the study. Informed consent was obtained from all participants.

All basic criteria of the study participants as age, residence, occupation, parity, educational level, history of FGM or not, age at FGM, the operator who performed FGM, occurrence of any immediate complications, presence of any sexual or organic problems, occurrence of any obstetric problems in past deliveries were obtained. Local examination was performed to detect the type of FGM, presence of any scars

All data were analyzed using SPSS software Chicago, IL, USA, version 21. Comparison between categorical variables in both groups was done by Chi-square test and continuous variables were compared using Student T-test. We considered $\mathrm{P}$ value $<0.05$ as a significant value.

\section{RESULTS}

Table 1 shows the demographic characteristics of the study participants. The study included 1175 women, from whom $89.1 \%$ were circumcised. Type 1 FGM was the most prevalent type practiced in about $58 \%$ of participants. Nearly half $(49.4 \%)$ of the study participants were house wives, while the rest were workers. Moreover, about $313(26.6 \%)$ of them cannot read and write whereas $176(15 \%)$ have secondary education above grade and $130(11.1 \%)$ have university level education. Most of respondents who undergone FGM said that it was performed by physicians (58.4\%) followed by midwives $(28.6 \%)$. 
Table 1: The demographic criteria of the study participants.

\begin{tabular}{|l|l|}
\hline Variables & Study participants $(\mathbf{n}=\mathbf{1 1 7 5})$ Number $(\%)$ \\
\hline Circumcised & $1047(89.1)$ \\
\hline Yes & $128(10.9)$ \\
\hline Residence & $580(49.4)$ \\
\hline Rural & $595(50.6)$ \\
\hline Urban & \\
\hline Educational level & $313(26.6)$ \\
\hline Illiterate & $291(24.8)$ \\
\hline Read and write & $265(22.6)$ \\
\hline Primary & $176(15.0)$ \\
\hline Secondary & $130(11.1)$ \\
\hline University & \\
\hline Occupation & $580(49.4)$ \\
\hline House wife & $595(50.6)$ \\
\hline Employee & \\
\hline Who did FGM? (n=1047) & $299(28.6)$ \\
\hline Midwife & $46(4.4)$ \\
\hline Barber & $91(8.7)$ \\
\hline Nurse & $611(58.4)$ \\
\hline Physician & \\
\hline Types of FGM (n=1047) & $613(58.5)$ \\
\hline Type 1 & $434(41.5)$ \\
\hline Type 2 & \\
\hline FGM: female genital mutilation & \\
\hline
\end{tabular}

Table 2: The reported complications among the study participants.

\begin{tabular}{|c|c|}
\hline Variables & Study participants Number (\%) \\
\hline \multicolumn{2}{|l|}{ Immediate complications: $(n=447,42.6 \%)$} \\
\hline Primary hemorrhage & $172(38.5)$ \\
\hline Infection at circumcision wound & $107(23.9)$ \\
\hline Urinary retention & $80(17.9)$ \\
\hline Dysuria & $43(9.6)$ \\
\hline Injury to the vulva or vagina & $45(10.1)$ \\
\hline \multicolumn{2}{|l|}{ Sexual problems: $(n=429,40.9 \%)$} \\
\hline $\begin{array}{l}\text { Disturbance in relationship (loss of libido, sexual desire and failure to reach } \\
\text { orgasm) }\end{array}$ & $320(74.6)$ \\
\hline No sexual satisfaction & $76(17.7)$ \\
\hline Separation from husband & $33(7.7)$ \\
\hline \multicolumn{2}{|l|}{ Organic problems: $(n=212,20.2 \%)$} \\
\hline Chronic pelvic inflammatory diseases & $72(34.0)$ \\
\hline Urinary troubles & $32(15.1)$ \\
\hline Infertility & $44(20.8)$ \\
\hline Serious viral infection like hepatitis & $64(30.2)$ \\
\hline \multicolumn{2}{|l|}{ Obstetrics complications: $(n=496,47.3 \%)$} \\
\hline Caesarean section due to obstructed labor & $192(38.7)$ \\
\hline Multiple vaginal tears & $179(36.1)$ \\
\hline Postpartum hemorrhage & $125(25.2)$ \\
\hline
\end{tabular}

Table 2 shows the reported complications among study participants. Immediate complications occurred in $42.5 \%$ of women. Primary hemorrhage during circumcision was the most commonly reported immediate complication among $38.5 \%$ of them. Sexual problems were found in $40.5 \%$ of participants. Sixty-four women reported occurrence of hepatitis virus infection after the procedure. Moreover, 44 women were suffered from infertility and 
72 women had an episode or chronic PID. Table 3 shows the relation between demographic criteria of the study participants and their intention to circumcise their daughters. Women who intend to circumcise their daughters are mostly those coming from rural areas $(\mathrm{p}=0.000)$ and housewives $(\mathrm{p}=0.000)$. Most of women $(45.8 \%)$ who have the intent to circumcise their daughters claiming that it is religious based (Table 4).

Table 3: Relation between demographic criteria of the study participants and their intention to circumcise their daughters.

\begin{tabular}{|c|c|c|c|}
\hline Variables & Will not circumcise their daughters & Will circumcise their daughters & p- value \\
\hline \multicolumn{4}{|c|}{ State of circumcision } \\
\hline Not circumcised & $128(100)$ & $0(0)$ & \multirow[t]{2}{*}{0.000} \\
\hline Circumcised & $502(47.9)$ & $545(52.1)$ & \\
\hline \multicolumn{4}{|l|}{ Residence } \\
\hline Rural & $227(39.1)$ & $353(60.9)$ & 0.000 \\
\hline Urban & $403(67.7)$ & $192(32.3)$ & \\
\hline \multicolumn{4}{|l|}{ Educational level } \\
\hline Illiterate & $212(67.7)$ & $101(32.3)$ & \\
\hline Read and write & $144(49.5)$ & $147(50.5)$ & 0.000 \\
\hline Primary & $137(51.7)$ & $128(48.3)$ & \\
\hline Secondary & $78(44.3)$ & $98(55.7)$ & \\
\hline University & $59(45.4)$ & $71(54.6)$ & \\
\hline \multicolumn{4}{|l|}{ Occupation } \\
\hline House wife & $227(39.1)$ & $353(60.9)$ & 0.000 \\
\hline Employee & $403(67.7)$ & $192(32.3)$ & \\
\hline
\end{tabular}

Table 4: The reasons of the study participants for intention to circumcise their daughters or not.

\begin{tabular}{|c|c|c|c|}
\hline & $\begin{array}{l}\text { Women who have no } \\
\text { intent to circumcise their } \\
\text { daughters }(n=630)\end{array}$ & & $\begin{array}{l}\text { Women who have intent to } \\
\text { circumcise their daughters } \\
(\mathrm{n}=545)\end{array}$ \\
\hline $\begin{array}{l}\text { Confident that it has no } \\
\text { benefit }\end{array}$ & $373(59.2)$ & Religious based & $250(45.8)$ \\
\hline Not religious based & $33(5.2)$ & Traditional habit & $150(27.5)$ \\
\hline $\begin{array}{l}\text { Has many medical and } \\
\text { psychological problems }\end{array}$ & $224(35.6)$ & To decrease sexual desire & $145(26.7)$ \\
\hline
\end{tabular}

\section{DISCUSSION}

There have been no comprehensive global surveys of prevalence of FGM. However, WHO estimated that 132 million of girls and women have under gone the operation and two million girls are at risk each year in 28 African countries with estimated prevalence of $90 \% .^{11}$ Report by United nation population fund (UNFPA) indicated that the production and sexual health were affected over the entire life by FGM; despite the problem, it is still practiced, because of culture significance. Finally, it is important to bear in mind that FGM is dangerous and humiliating traditional practice that violates the right of girls and women and it is serous public health problems as it affects the health of poor girls and women.

The most frequent age group for circumcision in our study was 6 years followed by 5 years which correlate with other previous studies that were found that the average age at which circumcision occurs was 6.06 years. Another one found that the mean age of circumcision was 8.04 years. All these studies informed us that the time of circumcision is usually just before onset of menarche to give the female the impression that she starts womanhood life. ${ }^{12,13}$

In the present study, we found that the percentage of circumcision in urban residence $(50.4 \%)$ that was near the percentage of circumcision in rural residence $(49.6 \%)$ and this differ from one study in Egypt, in which the prevalence of circumcision was more common among rural area $(68.5 \%)$ than city $(31.5 \%)$. The explanation was that our study result was the actual one which reflects that circumcision is traditional habit rooted upon religious base not actually affected by residence.

Regarding educational level the percentage of women in the study was $22.6 \%$ illiterate, $24.8 \%$ read and write, $22.6 \%$ primary school, $15 \%$ secondary school, and $11.1 \%$ 
university plus post graduate. Regarding occupation 49.6\% was housewife and $50.4 \%$ was employee which differs from two studies in Egypt which found that the proportion that supports circumcision rose from $57 \%$ among women with secondary or higher education to reach $98 \%$ among women with no schooling. All these studies including our study confirms that higher levels of education indicated lower levels of support for circumcision. ${ }^{14}$ The explanation is that our study result was the actual one which reflect that circumcision is traditional habit rooted upon religious base not actually affected by educational level.

Immediate complications had occurred in $42.6 \%$ of cases in our study with the following sequence: primary hemorrhage $38.5 \%$, wound infection $23.9 \%$, urinary retention $17.9 \%$, dysurea $9.6 \%$, injury to the vulva or vagina $10.1 \%$. This agree with one study which found that the primary complication occurred in $(39.3 \%)$ with $23.8 \%$ 1ry hemorrhage $(25 \%)$ infection and $13 \%$ urinary complications in form of retention or dysuria and abnormal walking. ${ }^{15}$ Additionally, another study found that the primary complications directly after female circumcision mainly hemorrhage $(28.8 \%)$ and wound infection in $20 \%$, urine retention $(19.8 \%$ ) and vulvar or vaginal injury in $(6.5 \%){ }^{16}$

Sexual problem has occurred in $40.9 \%$ cases of our study in the following sequences: (Disturbance in relationship (loss of libido, sexual desire and failure to reach orgasm $74.6 \%$, non-sexual satisfaction $17.7 \%$ and separation from husband $7.7 \%$. This agree with the following researcher comment who observed that Sexual complications took multiple forms from difficulties during intercourse in the form of (pain, fear, vaginismus), failure to reach orgasm which found in $(16.61 \%)$ of circumcised females, these sexual problems caused separation from partner in 46 cases of circumcised females $(4.39 \%) .{ }^{15}$

Long term organic complications in our study had occurred in $20.2 \%$ of cases in the following sequences: chronic pelvic inflammatory disease 34\%, urinary troubles $15.1 \%$, infertility $20.8 \%$ and serious viral infection like hepatitis 30.1. This agree with the following study which found that $(15.7 \%)$ have pelvic pain and $(5 \%)$ with urinary symptoms and $(2.3 \%)$ with hepatitis between those whom circumcised ${ }^{17}$

Obstetrics complication had occurred in $47.9 \%$ of cases in our study by the following sequences: cesarean section due to obstructed labor $38.7 \%$, multiple vaginal tears $36.1 \%$, and post-partum hemorrhage $25.2 \%$ which agree with one study in which it was found that $10.41 \%$ of circumcised cases had cesarean section due to labor difficulties. Also, the rigidity of the circumcision scar may force the fetal head posterior and cause severe perineal laceration. ${ }^{8}$

In our study 630 women $(53.6 \%)$ from total women intent not to circumcise their daughters, but from total circumcised women (1047) only 502 women (47.9\%) intent not to circumcise her daughters. Regarding residence, $64 \%$ from total women who intent not to circumcise her daughter were from urban residence. One of the important point is that the higher percentage of women who intent not to circumcise her daughters were from low educational level categories. Regarding occupation $64 \%$ from total women who intent not to circumcise her daughter were employee, all of the previous 4 items agrees with the following study which found that the overall prevalence of genital cutting was reportedly $50.3 \%$ among girls. In rural schools, the prevalence rate was $61.7 \%$ compared to $46.2 \%$ in urban schools. ${ }^{18}$

The percentage of women who will not intent to circumcise her daughter according the reason for that was in the following sequences: they were confident that it has no benefit $(59.2 \%)$, not religious based $(5.2 \%)$, has many medical and psychological problem $(35.6 \%)$. This agrees with one study in which, $53.9 \%$ of noncircumcised girls said that genital cutting is not important and that it is an unhealthy and painful procedure, while $17.5 \%$ of girls said that it is unnecessary for females. Around $12 \%$ of girls in believed that there is no religious support for circumcision. ${ }^{18}$

Percentage of women who will intent to circumcise her daughter according the reason for that was in the following sequences: religious based $(45.8 \%)$, traditional habit $(27.5 \%)$ and to decrease sexual desire $(26.7 \%)$ which agree with one study in which the girls were asked for reasons to support the practice of genital cutting. Their answers included that FGM is an important religious tradition $(33.4 \%)$, the practice helps ensure cleanliness for girls $(18.9 \%)$, it is a cultural and social tradition $(17.9 \%)$, and it promotes chastity $(15.9 \%){ }^{18}$

\section{CONCLUSION}

From our observation of the results we found that the prevalence of FGM did not differ between urban and rural or between house wives and employee, lastly did not differ between different educational levels as most of them were encourage it thinking that it is of traditional, religious base and protect the girl from any abnormal sexual excitation. The women who intent not circumcise their daughters were from low educational level in its highest percentage and this was explained by occurrence of higher percentage of complications in spite of the highest percentage of operator was physician.

\section{Recommendations}

Training courses for the house officer physician to explain the physiological, sexual and psychological aspect of FGM in addition to good anatomical details and complications. Good contact from leaders of the community especially highest religious authority in Egypt, Al-Azhar, with male and female students to speak 
against FGM. As future husband support for her future wife to be against FGM has great role.

Funding: No funding sources

Conflict of interest: None declared

Ethical approval: The study was approved by the Institutional Ethics Committee

\section{REFERENCES}

1. World Health Organization. Female Genital Mutilation: Fact Sheet No 241. 2013. Available form http://www.who.int/mediacentre/factsheets/fs241/en.

2. Mawad NM, Hassanein OM. Female circumcision: three years'experience of common complications in patients treated in Khartoumteaching hospitals. J Obstet Gynaecol. 1994;14:40-3.

3. Momoh C. Female genital mutilation. Curr Opin Obstet Gynecol. 2004;16:477-80.

4. Egyptian demographic health survey 2000, Egyptian ministry of health; 2003.

5. The Department of Health. CMO Update 37. London: Department of Health; 2004.

6. Dare FO, Oboro VO, Fadiora SO, Orji EO, Sule-Odu AO, Olabode TO. Female genital mutilation: an analysis of 522 cases in South-Western Nigeria. J Obstet Gynaecol. 2004;24:281-3.

7. al-Sabbagh LM. The Right Path to Health: Health Education through Religion. Islamic Ruling on Male and Female Circumcision. Alexandria, Egypt: WHO Regional Office for the Eastern Mediterranean; 1996.

8. Rashid M, Rashid MH. Review of obstetric management of women with female genital mutilation (Review). Obstet Gynaecol. 2007;9:95101.

9. Abolfotouh SM, Ebrahim AZ, Abolfotouh MA. Awareness and predictors of female genital mutilation/cutting among young health advocates. Int J Women's Health. 2015;7:259-69.
10. Afifi M. Egyptian ever-married women's attitude toward discontinuation of female genital cutting. Singapore Med J. 2010;51(1):15-20.

11. World Health Organization, Eliminating female genital mutilation an interagency statements UNAIDS, UNDP, UNECA, UNESCO, UNFPA, UNHCHR, UNHCR, UNICEF. Switzerland WHO Geneva; 2008.

12. Cunter LP. Female genital mutilation. Obstet Gynecol Surv. 1999;40(77):437-43.

13. Yoder PS, Khan S. Numbers of Women Circumcised in Africa: The Production of a Total; 2008.

14. El-Defrawi, MH, Lotfy, G, Dandash, KF, Refaat, AH, Eyada, M. Female genital mutilation and its psychosexual impact. J Sex Marital Ther. 2001;27:465-73.

15. Aziz FA. Gynecologic and Obstetric complications of female circumcision: Int $\mathrm{J}$ Gynecol Obstet. 2010:17:560-3.

16. Leye E, Powell RA, Nienhuis G, Claeys P, Temmerman M. Health care in Europe for women with genital mutilation. Health Care Women Int. 2006;27:362-78.

17. Chibber R, El-Saleh E, El Harmi J. Female circumcision: obstetrical and psychological sequelae continues unabated in the 21 st century. J Matern Fetal Neonatal Med. 2011;24:833-6.

18. Verzin J. Sequelae of female circumcision. Trop Doct. 1975;5:163-9.

Cite this article as: Mitwaly $\mathrm{ABA}, \mathrm{Abd} \mathrm{El} \mathrm{Aal}$ DEM, Aziz PA, Hassanin AI, Abbas AM. A recent look for the implication and attitude of practicing female genital mutilation in upper Egypt: a cross sectional study. Int J Reprod Contracept Obstet Gynecol 2017;6:4224-9. 